\title{
THE FACTORS EFFECT ON BRAND EQUITY IN HIGHER EDUCATION
}

\author{
NGUYỄN VĂN THANH TRƯÒNG \\ Khoa Quản trị Kinh doanh, Truòng Đại học Công nghiệp Thành phố Hồ Chi Minh \\ nguyenvanthanhtruong@iuh.edu.vn
}

\begin{abstract}
An issue of university development is the increasing stratification that significantly affects a higher education institution's enrollment and benefit. The higher education institution has realized that the brand increases recognized as an essential determinant of learner choice. The study identifies the components of perceived quality in higher education and examines the model of perceived quality and reputation effect on brand equity. With qualitative and quantitative research methods, the results confirm the four-factor structure of perceived quality and reputation influence brand equity in the higher education sector. The study asserts that perceived quality is considered a reflective construct, including library services, dining service, physical facilities, and academic staff responsiveness. Some managerial implications are proposed based on the research result.
\end{abstract}

Keyword. Perceived quality; reputation; reflective construct validation; brand equity; higher education.

\section{CÁC YẾU TỐ XÁC ĐỊNH GIÁ TRI THƯƠNG HIỆU TRƯờnG ĐẠI HỌC}

Tóm tắt. Thách thức cho sự phát triển của giáo dục đại học là gia tăng phân tầng các trường đại học mà ảnh hưởng mạnh đến lợi ích của các trường đại học. Các cơ sở giáo dục đại học đã nhận ra rằng thương hiệu ngày càng được cổng nhận là một yếu tố quyết định thiết yếu đến sự lựa chọn của người học. Nghiên cứu đã xác định các thành phần của chất lượng cảm nhận trong giáo dục đại học và xem xét sự phù hợp của mô hình của chất lượng cảm nhận và ảnh hưởng danh tiếng đối với giá trị thương hiệu. Với phương pháp nghiên cứu định tính kết hợp với phương pháp nghiên cứu định lượng, kết quả đã khẳng định cấu trúc 4 yếu tố của chất lượng cảm nhận và danh tiếng ảnh hưởng đến giá trị thương hiệu trong lĩnh vực giáo dục đại học. Nghiên cứu khẳng định rằng chất lượng cảm nhận được coi là cấu trúc phản ánh bao gồm dịch vụ thư viện, dịch vụ ăn uống, cơ sở vật chất, khả năng đáp ứng của nhân viên giảng dạy. Một số hàm ý quản lý được đề xuất dựa trên kết quả nghiên cứu.

Từ khóa. Chất lượng; danh tiếng; độ giá trị cấu trúc phản ánh; giá trị thương hiệu; giáo dục đại học.

\section{INTRODUCTION}

As internationalization has become the focal point of higher education, competition has become a central preoccupation in developing countries. Higher education institutions are required to provide products and services to satisfy the stakeholder requirement about quality. Marginson (2011) used the terms massification, marketization, and managerialism to envisage the higher education market in the new situation based on data from studies in the UK and USA. The study also assesses that higher education institutions face the new situation and change cognitive thinking in vision and mission. The three factors create an entirely new situation in higher education lead to tremendous problems to its governance systems, curriculum development, research, and budgeting in the twenty-first century. One major trend of socialization and international integration related to reforming and restructuring higher education is making the higher education systems more globally competitive.

An issue of university development is the increasing stratification that significantly affects a higher education institution's enrollment and benefit. The hierarchy is legalized and maintained by the various QS rankings to represent the significant difference of function in the educational system -it is primarily relevant to that organization's research ability. Simultaneously, perceived quality and brand are also essential to the competitive environment in the higher education sector. It is relatively challenging due to the service's dominance characteristics and reducing perceived risk, which is generally higher in a service selection decision. Consumers evaluate to find services more difficult in advance of purchase. In this case, the brand can play an essential role in giving consumers greater confidence in their decision-making. Thus, the higher 
education institution has realized that the brand is increasingly recognized as an essential determinant of learner choice.

In marketing research, many scholars found the relationship between brand and consumer, and then they argue that the brand is the most valuable asset for any organization. M. Pinar, Trapp, P., Girard, T., \& E. Boyt, T. (2014) tested models of the brand and adapted them for use in the service sector and the specific context of higher education. However, the importance of perceived quality and brand reputation, which affect brand equity did not consider carefully. Although brand equity has received significant scholarly attention in recent years, limited research has been done in the context of higher education in Viet Nam (Perera, Nayak, \& Van Nguyen, 2020)

In a particular context as Viet Nam, the nation has a rapid economic - political - social transformation yearly. Thereby, the demand for high-quality human resources to meet government and society requirements is also increasing in the new period. The Ministry of Education and Training (MOET) has posed problems and challenges that need to be changed for universities and colleges. The focus of the new policy is to improve the quality - sustainable development - International integration. Therefore, the universities need to satisfy prestigious organizations' accreditation and assessment standards such as MOET, AUN-QA, ABET, ACBSP, or AACSB.

In 2016, the MOET issued The Vietnamese Qualifications Framework (VQF) on eight levels, simultaneously changing the existing accreditation criteria appropriate to the AUN-QA assessment criteria. Therefore, the universities have concomitantly adjusted strategies to meet the new requirements and situations. MOET's standards requirements meet stakeholders' requirements, including managers, students, academic staff, support staff, and businesses. Besides that, the higher education sector has competed between public and private universities to attract talented learners to maintain a competitive advantage. Within the study's scope, the authors identify antecedents of brand equity, including components of quality assessment of the perceived service quality, consistent communication to guarantee brand trust, and brand reputation as the basis for adjusting the measurement following be aligned condition of Vietnam Education. Therefore, the study reviewed the literature to identify components relevant to perceived quality and branding in the higher education sector. These factors are proposed to determine the relative importance of the brand equity dimensions as reputation in creating a solid university brand. The last discuss the implication of the findings for the marketing strategy of the university.

\section{LITERATURE REVIEW}

\subsection{Brand equity in higher education}

According to Aaker (1991), brand equity's components consist of five components: brand loyalty, brand awareness, perceived quality, brand associations, and another proprietary. Keller (1993) asserted that brand equity is customer knowledge of brand knowledge. In other words, customer-based brand equity is the distinct influence that brand knowledge creates on customer response to brand marketing. Value occurs when consumers have a high level of awareness and familiarity with the brand and have a robust, beneficial, and unique brand association in mind. The study has argued that customer knowledge includes brand image, brand awareness (brand recall and brand recognition). The brand image includes brand co-attributes (types of brand associations) such as attributes, benefits, attitudes, and favorability of brand associations; The uniqueness of the above qualities includes other sub-attributes such as functional, experiential, symbolic benefits. Lassar, Mittal, and Sharma (1995) found five brand equity components, including perceived quality, perceived value, brand image, trustworthiness, customers' feelings about commitment. Tho and Trang (2002) confirmed that the brand equity model consisted of four brand equity components, including brand awareness, perceived quality, attitudes, and brand passion, suitable for Vietnamese consumers.

In the higher education sector, following brand equity theories and customer-based brand equity models, Dung and Business (2019) proposed an analytical framework that adopts components of Aaker (1991), including brand awareness, brand associations, perceived quality, and brand loyalty to enhance the value of brand equity for higher institutions in Vietnam. The study of Tran, Nguyen, Do, and Nguyen (2020) about university students' insight on brand equity proved a significant relationship between brand awareness, brand loyalty, and brand equity. The study also verified the relationships between brand communication, brand trust, and brand image. In highlighting the study brand equity based on Vietnamese and Sri Lankan's perceived brand, Perera et al. (2020) found that perceived brand credibility is the mediating 
variable impact on brand equity. The location has a moderate relationship between perceived brand credibility and brand equity.

According to Ivy (2008), brand equity includes seven distinguishing factors (e.g., program, prominence, price, prospectus, people, promotion, and premiums) essential to selecting a university. Besides that, few other studies have focused on emphasizing peoples, processes in the marketing of services, and the tight linkage of positioning to the concept of branding. M. Pinar, Trapp, Girard, and Boyt (2011) proposed a higher education brand model for developing brand equity of a university. According to the study of Mourad, Ennew, Kortam, and Planning (2011) in the topic "Brand value in higher education" shows nine factors affecting brand value in universities, including Word of mouth, Marketing, Service quality perception, Price, Social image, Employee image, History, International relations, and Location. Research to explore in detail brand awareness and image properties that affect brand equity. The study's value is also shown by comparing the high school and university and the moderator variable first choice last choice.

Based on different contexts and approaches, it shows that research in brand equity still lacks the consistency of factors. Extensive studies in different aspects lead to modified results. However, the research on brand equity still ensures the inheritance and adjustment from Aaker (1991); Keller (1993)

\subsection{Hypothesis and Research model}

\subsubsection{The impact of perceived quality}

Many studies focus on different aspects of perceived quality in the higher education sector. However, the primary purpose-focused exploratory scale of measurement focuses on the relationship between perceived quality as antecedent brand equity is limited. Aaker (1991) mentioned perceived quality to be an essential component associated with brand equity. Zeithaml (1988) noted that perceived quality refers to customers' judgments about a products' overall excellence or superiority. Besides that, the evaluations of quality usually take place in a comparative context. The result of the empirical analysis indicates that perceived quality was also key significant in determining brand equity.

The perceived quality is considered an essential and direct impact on brand equity in the higher education sector. It provides a reason for customers to differentiate a brand from its competitors. Yoo, Donthu, and Lee (2000) estimated a direct relationship between perceived quality and brand equity; however, the result shows a weak association between perceived quality and brand equity. Most investigations explore the direct link between perceived quality and brand equity in the manufacturing context (Jahanzeb, Fatima, \& Mohsin Butt, 2013). He and Li (2010) investigated the relationship between overall service quality and the consumer-based brand equity of a service brand. The indicates that the empirical evidence to support a direct link between perceived quality of service and brand equity is far from conclusive and needs further investigation. Based on the above discussion, therefore, this study presents the following hypothesis:

Hypothesis 1: The perceived quality in higher education has a positive influence on brand equity.

2.2.2. The impact of reputation

According to the higher education sector's international integration trend, higher education institutions pay more attention to the brand in competitive categories adopt both depth and breadth strategies. Higher education institutions conducted image reconstruction strategies to re-position themselves in the education market and improve their reputation (Brown \& Geddes, 2006). Although scholars of marketing still have substantial brand research in many sectors, publishing on the brand in higher education branding seems limited (Hemsley-Brown \& Oplatka, 2006).

A study by Sevier (1994) found that reputation is the most critical factor which affects prospective students' decision to attend a university. Similarly, Berger and Wallingford (1997) stated that factors that are essential in choosing a university are "reputation" and "academics." Mazzarol and Soutar (2012) mentioned "strong reputation" as one of the critical competencies for education institutions to successfully compete in the global market. Sultan and Yin Wong (2012) stated that a university's reputation is outstanding in a competitive market. Reputation is the overall value, esteem, and character how a firm's prospects compared to those of competing organizations (Fombrun \& Shanley, 1990). According to Chen and Hsiao (2009), reputation impacts students' intent to choose the university.

Hypothesis 2: The brand reputation in higher education has a positive influence on brand equity.

\section{RESEARCH METHODOLOGY}

The research methodology combined qualitative and quantitative methods to achieve its objectives. The mixed-method helps to increase the accuracy of validity and reliability (Babbie, 2020). The study used 
qualitative research to identify perceived quality components and the factors related to brand equity. Methods of data collection in qualitative research were in-depth interviews using open-ended questions and focus group discussions.

Based on the results of ten in-depth interviews, eight of the applicants mentioned that the university's brand equity had indicated the reputation and the perceived quality of the training and service. In particular, the applicants have believed that the perceived quality of classroom, library resources, library personnel, food service, lifts, practice room, lab, and facilities make value for the university brand. Besides that, three of the applicants considered the dormitory's quality, and all applicants agreed that the academic staff's responsiveness is an essential factor. To sum up, the results showed that students are interested in facilities, library services, dining services, and faculty responsiveness. Besides that, some students who live in the dormitory also mentioned the services at the dormitory. However, the dormitory did not reflect all students' standard service, so it was rejected during the focus group discussion. In the next step, questionnaires based on qualitative research and questions inherited from previous studies were developed and tested in quantitative analysis.

The quantitative research conducted a face-to-face interview for a survey in Ho Chi Minh City - Viet Nam. The data collection had born in December 2019. Two male and three female undergraduate students trained for the data collection. The number of participants was 285; the sample consisted of 147 men $(51.6 \%)$ and 138 women (48.4\%). Four items were adapted from Tong and Hawley (2009) to measure reputation. The perceived quality construct consisted mainly of library service, dining services, and physical facilities were adapted from Gray, Shyan Fam, and Llanes (2003) and academic staff adapted from M. Pinar, Trapp, P., Girard, T., \& E. Boyt, T. (2014). The four items of brand equity were adapted from Yoo and Donthu (2001). In the higher education sector, Kurz, Scannell, and Veeder (2008) found factors as components of perceived quality include the responsiveness of the academic staff, support staff, and service affairs in the higher education institution. The study investigated perceived quality base on value-creation activities that include library services, dining service, physical facilities as the role of multidimensional to measure support. Besides that, students' learning experience was also noted in mind through interaction activities between learner and academic staff, then perceived quality in higher education were considered as reflective construct including library services, student living, physical facilities, and responsiveness of the academic staff. The study also found the relationship between perceived quality and brand equity in the second-order model.

A structural equation model (SEM) examined the relationships between perceived quality, brand reputation, and connection with brand equity to analyze the structure model. Respondents answered on five-point scales for all constructs.

Table 1 shows that all research items are developed based on previous studies' original scales and adjusted during qualitative research. The model has six constructs with 33 items, which are measured by the 5-point Likert scales.

\begin{tabular}{|c|c|c|c|}
\hline Construct & Code & The content of scales & Source \\
\hline \multirow{8}{*}{ Reputation } & REP1 & $\begin{array}{l}\text { The university's graduates are employed before or soon } \\
\text { after graduation }\end{array}$ & \multirow{8}{*}{$\begin{array}{l}\text { Adapted from M. Pinar, Trapp, P., } \\
\text { Girard, T., \& E. Boyt, T. (2014) and } \\
\text { new items from qualitative research }\end{array}$} \\
\hline & REP2 & The university has a well-known academic reputation & \\
\hline & REP3 & The university has high academic standards & \\
\hline & REP4 & The university's graduates receive reasonable job offers & \\
\hline & REP5 & The university's graduates have successful careers & \\
\hline & REP6 & $\begin{array}{l}\text { Based on the cost of tuition, the university offers a good } \\
\text { educational value }\end{array}$ & \\
\hline & REP7 & Companies prefer recruiting the university's graduates & \\
\hline & REP8 & $\begin{array}{l}\text { The university offers well-known international degree } \\
\text { programs (Canada, Korea). }\end{array}$ & \\
\hline
\end{tabular}




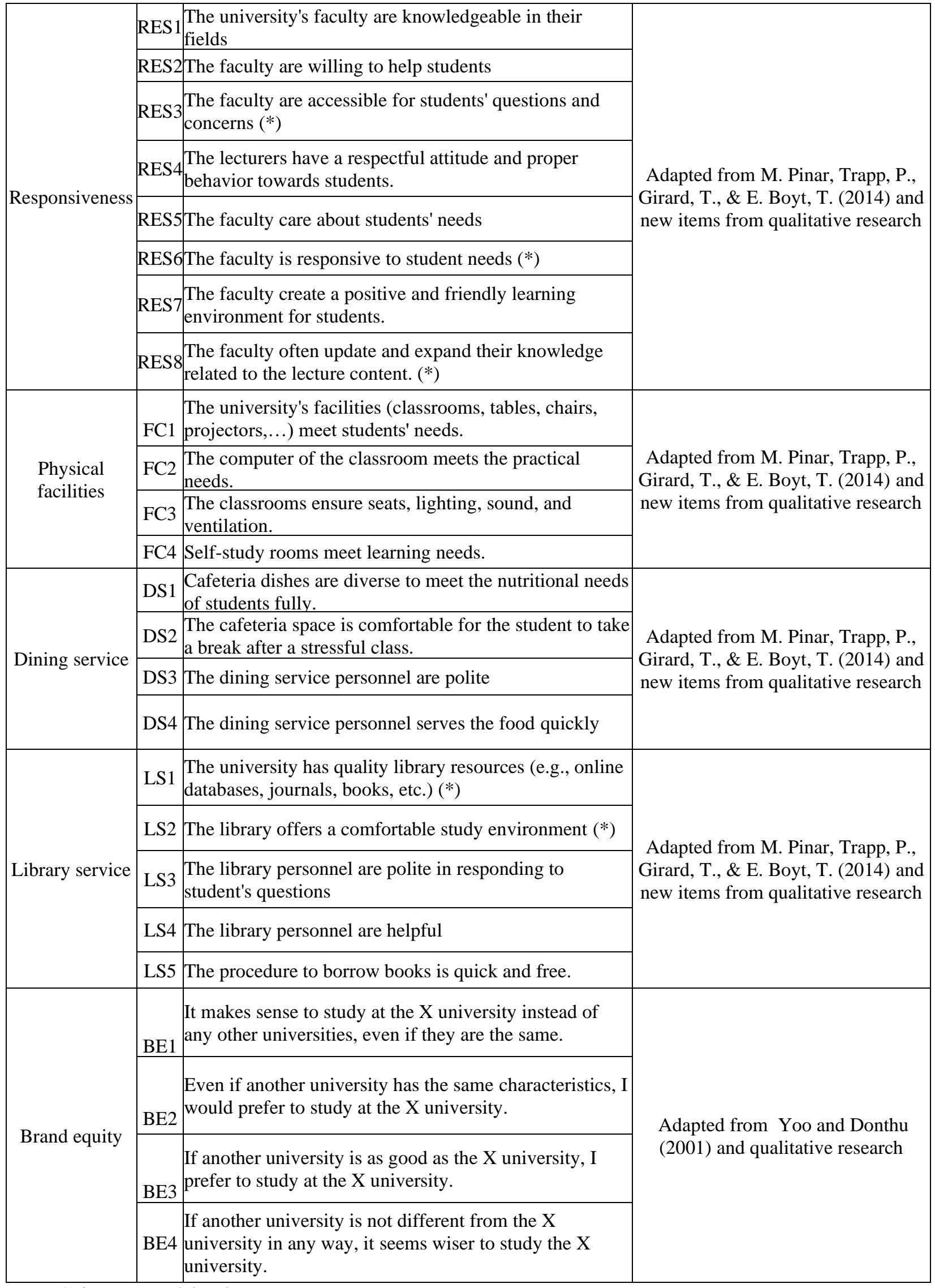

Note: (*) items were deleted.

$\mathrm{X}$ indicated a brand name of the university 


\section{RESULTS}

\subsection{EFA - Exploratory Factor Analysis}

The EFA analysis adjusted and conducted three times; the result showed the rotated factor matrix of independent and dependent variables had the factor loading of items was more than 0.5. The result also eliminated items with the factor loading that were less than 0.5 consists of REP5, REP8, RES3, RES6, and LS2. The next step, the study, was conducted to analyze Cronbach's Alpha to confirm the above factors to ensure the reliability of factors. The result of Cronbach's alpha ensured that items Cronbach's alpha $>0.6$ and Corrected Item Total Correlation > 0.3 match the condition follows per Peterson (1994). (The detail of the result showed table 2)

Table 2. The EFA result and Cronbach's Alpha

\begin{tabular}{|c|c|c|c|c|c|c|c|}
\hline \multicolumn{7}{|c|}{ EFA Analysis } & \multirow{2}{*}{ Cronbach's Alpha } \\
\hline & REP & RES & DS & $\mathbf{B E}$ & FC & LS & \\
\hline RES3 & $\underline{.836}$ & .166 & .067 & .099 & .017 & .140 & \multirow[t]{6}{*}{.865} \\
\hline RES2 & .810 & .202 & .095 & .162 & .127 & .011 & \\
\hline RES4 & .776 & .180 & .070 & .123 & .157 & .170 & \\
\hline RES7 & .733 & .171 & .090 & .180 & .164 & .128 & \\
\hline RES1 & .681 & .203 & .189 & .036 & .115 & .163 & \\
\hline RES5 & .650 & .136 & .026 & .191 & .102 & .262 & \\
\hline REP4 & .136 & .797 & .034 & .198 & .052 & .104 & \multirow[t]{6}{*}{.874} \\
\hline REP1 & .163 & .735 & .114 & .166 & -.011 & .201 & \\
\hline REP5 & .216 & .716 & .089 & .005 & .129 & .066 & \\
\hline REP2 & .117 & $\overline{.660}$ & .183 & .285 & .001 & .202 & \\
\hline REP7 & .239 & .615 & .087 & .318 & .061 & .062 & \\
\hline REP8 & .350 & .517 & .012 & .154 & .235 & .091 & \\
\hline DS2 & .106 & .101 & .772 & .132 & .167 & .120 & \multirow[t]{4}{*}{.837} \\
\hline DS4 & .100 & .065 & .761 & .110 & .230 & .100 & \\
\hline DS3 & .104 & .127 & .760 & .143 & .113 & .160 & \\
\hline DS1 & .072 & .102 & .754 & .210 & .135 & .190 & \\
\hline BE3 & .228 & .285 & .147 & .751 & .229 & .153 & \multirow[t]{4}{*}{.885} \\
\hline BE1 & .211 & .233 & .229 & .744 & .138 & .178 & \\
\hline BE2 & .177 & .233 & .214 & .742 & .150 & .170 & \\
\hline BE4 & .173 & .365 & .205 & .621 & .180 & .130 & \\
\hline LS3 & .087 & .076 & .153 & .179 & .819 & .124 & \multirow[t]{4}{*}{.824} \\
\hline LS4 & .108 & .030 & .180 & .169 & .815 & .119 & \\
\hline LS5 & .241 & .035 & .250 & .279 & $\overline{.663}$ & .139 & \\
\hline LS2 & .268 & .273 & .224 & -.064 & .592 & .209 & \\
\hline FC1 & .209 & .174 & .129 & .060 & .111 & $\underline{.810}$ & \multirow[t]{4}{*}{.821} \\
\hline FC2 & .133 & .206 & .205 & .087 & .139 & .731 & \\
\hline FC3 & .164 & .064 & .243 & .297 & .133 & .689 & \\
\hline FC4 & .307 & .179 & .102 & .194 & .202 & .606 & \\
\hline \multicolumn{5}{|c|}{ KMO } & \multicolumn{3}{|c|}{$0.5<0.911<1$} \\
\hline \multicolumn{5}{|c|}{ Bartlett's test sig. } & \multicolumn{3}{|c|}{0.000} \\
\hline \multicolumn{5}{|c|}{ Eigenvalues } & \multicolumn{3}{|c|}{1.141} \\
\hline \multicolumn{5}{|c|}{ Explained } & \multicolumn{3}{|c|}{$66.558 \%>50 \%$} \\
\hline
\end{tabular}




\subsection{CFA - Confirmatory Factor Analysis}

According to the procedure of Anderson and Gerbing (1988), the remaining 28 items were examined through CFA to establish each emerging factor's unidimensionality. A measurement model was thus specified and estimated using the AMOS 22 maximum likelihood method (Santoso, 2015). The measurement model turned out to be a poor representation of the data, with fit indices failing to meet acceptable levels (Hu \& Bentler, 1999)

The perceived quality evaluation involved testing the four components' validity and reliability, including library services, dining service, physical facilities, and academic staff responsiveness. The results of the initial CFA indicated that the data fit the model reasonably well, GFI $=0.897$; CFI $=0.926$; TLI $=0.913$. The items of perceived quality were significant and ranged from 0.62 to 0.80 . Internal consistency was demonstrated through the composite reliability scores, ranging from 0.812 to 0.883 (Table 3).

Next step, a single factor structure composed of all four perceived quality components was also analyzed to assess the perceived quality. However, the result showed that the single factor structure provided a much weaker fit, indicating that the perceived quality is not unidimensional. The proposed hierarchical structure of perceived quality (Figure 1) suggests that perceived quality's unidimensional nature may be apprehended through a second-order latent variable. Support for a second-order latent variable was also found in the correlations among the supporting and academic staff factors. The results support to confirm that conceptualizes the measurement model of perceived quality in higher education as a second-order reflective construct with four first-order reflective constructs based on a four-dimensional view of library service, dining services, physical facilities, and responsiveness of the academic staff. (Table 4)

CFA is used to evaluate the unidimensionality of reputation. The model was asserted, and no fit indices were provided. The composite reliability and AVE for Reputation were 0.866 and 0.520 , respectively. The item (indicator) loadings for the reputation were significant and ranged from 0.61 to 0.80 (Table 3). There are not problematic items were found in the initial CFA using.

The unidimensional check of the four items adapted from Yoo and Donthu (2001) to measure Brand equity was analyzed through CFA. The results indicated that the data of brand equity fit the model well (GFI = 0.975; CFI $=0.981$; TLI $=942 ; \mathrm{RMR}=0.019$ ). The composite reliability and coefficient alpha analysis were 0.866 and 0.662 , respectively, and the indicator loadings for the brand equity were all significant and ranged from 0.72 to 0.85 (Table 3). Fornell and Larcker (1981) demonstrated discriminant validity that the shared variance among any two constructs is less than the average variance extracted value of each construct. Table 5 showed that the square root of AVE was higher than the correlations for six factors.

Table 3. The CFA results of perceived quality, reputation, and brand equity constructs

\begin{tabular}{|c|c|c|c|c|c|c|c|c|c|c|}
\hline Factors & $\begin{array}{l}\text { No. } \\
\text { Items }\end{array}$ & $\begin{array}{l}\text { Composite } \\
\text { reliability }\end{array}$ & AVE & $\begin{array}{c}\text { Parameter } \\
\text { estimate }\end{array}$ & $\square \square$ square & df & GFI & CFI & TLI & RMR \\
\hline Perceived quality & & & & & & & & & & \\
\hline Dining service & 4 & 0.839 & 0.567 & $0.73-0.77$ & \multirow{4}{*}{310.998} & \multirow{4}{*}{131} & \multirow{4}{*}{0.897} & \multirow{4}{*}{0.926} & \multirow{4}{*}{0.913} & \multirow{4}{*}{0.049} \\
\hline Library service & 4 & 0.830 & 0.552 & $0.62-0.79$ & & & & & & \\
\hline Responsiveness & 6 & 0.883 & 0.559 & $0.67-0.80$ & & & & & & \\
\hline Physical facilities & 4 & 0.812 & 0.520 & $0.70-0.77$ & & & & & & \\
\hline Reputation & 6 & 0.866 & 0.520 & $0.61-0.80$ & 26.689 & 9 & 0.97 & 0.975 & 0.958 & 0.022 \\
\hline Brand equity & 4 & 0.886 & 0.662 & $0.72-0.85$ & 14.149 & 2 & 0.975 & 0.981 & 0.942 & 0.019 \\
\hline
\end{tabular}

Table 4. The result of the second-order construct of perceived quality

\begin{tabular}{|c|c|c|c|c|c|c|c|}
\hline \multicolumn{2}{|r|}{ Path } & $\begin{array}{c}\text { Standardized } \\
\text { loading }\end{array}$ & $\begin{array}{c}\chi \\
\text { square }\end{array}$ & df & CFI & TLI & RMR \\
\hline$\gamma 1$ & Perceived service quality -> Dining service & 0.69 & \multirow{4}{*}{654.34} & \multirow{4}{*}{343} & \multirow{4}{*}{0.917} & \multirow{4}{*}{0.925} & \multirow{4}{*}{0.045} \\
\hline$\gamma 2$ & Perceived service quality $->$ Library service & 0.73 & & & & & \\
\hline$\gamma 3$ & Perceived service quality -> Responsiveness & 0.70 & & & & & \\
\hline$\gamma 4$ & Perceived service quality $->$ Physical facilities & 0.815 & & & & & \\
\hline
\end{tabular}


Table 5. Discriminant validity of constructs in the model

\begin{tabular}{|l|c|c|c|c|c|c|}
\hline & Reputation & Brand equity & $\begin{array}{c}\text { Physical } \\
\text { facilities }\end{array}$ & $\begin{array}{c}\text { Dining } \\
\text { service }\end{array}$ & $\begin{array}{c}\text { Library } \\
\text { service }\end{array}$ & Responsiveness \\
\hline Reputation & $\mathbf{0 . 7 2}$ & & & & & \\
\hline Brand equity & 0.68 & $\mathbf{0 . 8 5}$ & & & & \\
\hline Physical facilities & 0.51 & 0.61 & $\mathbf{0 . 7 2}$ & & & \\
\hline Dining service & 0.46 & 0.55 & 0.53 & $\mathbf{0 . 7 5}$ & & \\
\hline Library service & 0.48 & 0.57 & 0.55 & 0.49 & $\mathbf{0 . 7 4}$ & \\
\hline Responsiveness & 0.51 & 0.61 & 0.59 & 0.53 & 0.54 & $\mathbf{0 . 7 5}$ \\
\hline
\end{tabular}

Notes: All correlations are significant at $\mathrm{p}=0.001$; the square root of AVE on diagonal

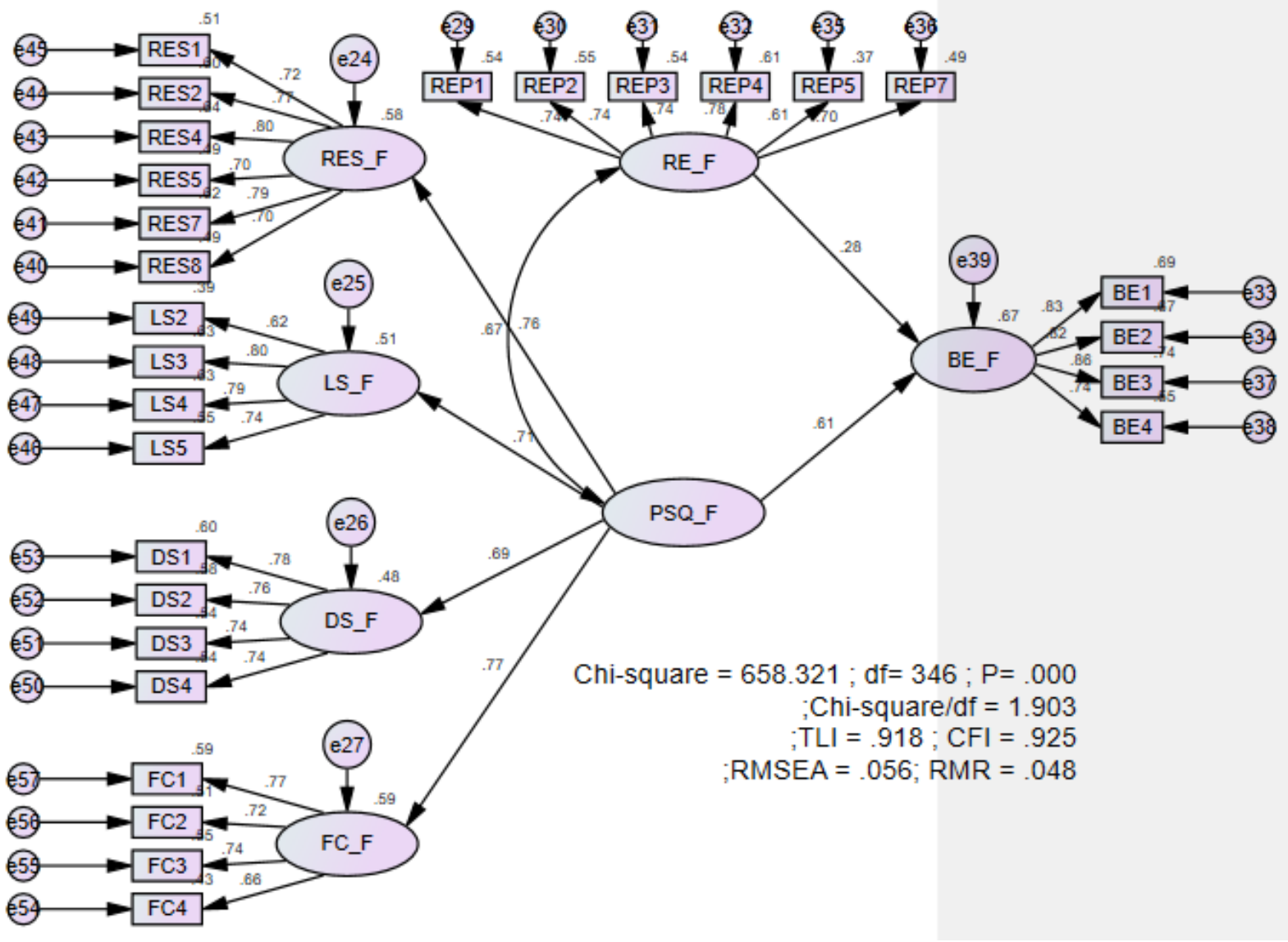

\subsection{Results and discussion}

Figure 1. The empirical result of the conceptual model

The model fit results indicated that the first model's data analyzed were satisfactory (CFI=0.925; $\mathrm{TLI}=0.918$; RMR $=0.048$ ). The indicators of discriminant and convergent validity are satisfactory and secure for the model. All items loaded significantly under their respective factors, demonstrating excellent reliability of the scales. The paths from perceived quality to brand equity were positive and significant (H1). Reputation (H2) had positive, statistically significant effects on brand equity. The result also asserted that the beta of perceived quality was more significant than the reputation impact on brand equity (Table 6).Table 
6. The result of the structural model and hypothesis testing

\begin{tabular}{|c|c|c|c|c|c|c|c|}
\hline & Path & $\begin{array}{c}\text { Standardized } \\
\text { loading }\end{array}$ & $\chi$ square & df & CFI & TLI & RMR \\
\hline$\beta 1$ & Perceived service quality -> Brand equity & 0.608 & \multirow{2}{*}{658.32} & \multirow{2}{*}{346} & \multirow{2}{*}{0.925} & \multirow{2}{*}{0.918} & \multirow{2}{*}{0.048} \\
\hline$\beta 2$ & Reputation $->$ Brand equity & 0.278 & & & & & \\
\hline
\end{tabular}

\section{CONCLUSION AND MANAGERIAL IMPLICATIONS}

Based on literature and hypothesis, this study combined several relationships, including library services, dining service, physical facilities, academic staff responsiveness, brand reputation, and brand equity. It proposed a framework to apply in the higher education sector. While there could be many perceptual factors for the student, the research focuses on the common aspects of student contact and experience. The study does not consider the dormitory, which is not the core service of most students.

Several impressive results emerged from the study. First, the results confirm the four-factor structure of perceived quality in the higher education sector. A unique contribution goes beyond the four-factor constructs, which allows the study to test and confirm a second-order latent variable structure. Second, the finding confirms the multidimensional nature of perceived quality, supporting the research of brand equity. The results indicate that perceived quality and reputation influence brand equity, while the perceived quality is the most robust effect to brand equity with a coefficient was 0.61 .

The study presents the analysis of the factors determining brand equity in the higher education sector, and the result has some dissimilarness compared to the model of Mourad et al. (2011). The study of Mourad et al. (2011) was conducted in Egypt, and the regression results showed that social image has the most decisive impact on brand value and perceived quality. On the other hand, the current study implements in the context of Vietnam, the model results determined that perceived quality has the most substantial effect on brand equity. In the comparison study about the Evaluation-Performance matrix of M. Pinar, Trapp, P., Girard, T., \& E. Boyt, T. (2014), the result confirmed that the perceived quality and reputation impact on brand equity, while the impact coefficient of perceived quality is higher than reputation. According to Denis's Dennis, Papagiannidis, Alamanos, and Bourlakis (2016), perceived quality determined no sign of the direct relationship to brand equity and weak reputation. However, both perceived quality and reputation indirectly affect brand equity through mediating factors.

The current study's conclusion recommends the interaction between a learner and a higher education institution significantly influences a good image in the learner's mind by its reputation and subsequent evaluation of quality perception.

\subsection{Managerial implications}

The research results point up that perceived quality is an essential factor for the university's brand equity. Many previous studies considered that reputation is an essential factor in the higher education sector; however, the study asserts reputation was also necessary, but the learners' perceptions about overall service quality are more important and must be prioritized for improvement development. The higher institutions should focus on improving the increasing quality to enhance brand equity in education services. To sum up, the research model could help higher education institutions better understand building a brand through brand equity. The perceived quality consists of support and responsiveness of academic staff to increase brand equity entirely. It is also essential to include a measure of brand reputation when assessing brand equity.

\subsection{Research implications}

There are implications for future research in the service of the higher education sector. First, the current research confirms that library services, dining service, physical facilities, and academic staff responsiveness are sub-dimensions of higher education institutions' perceived quality. However, other sub-dimensions of service delivery should be assessed as part of an institution's perceived quality.

Second, the study indicates reputation positively affects brand equity and recommends a university with a good reputation will increase brand equity.

Third, perceived quality and reputation had a more substantial influence on brand equity. Future research should consider the differential influence of perceived quality concerning diverse service offerings. 


\subsection{Limitations of this study}

The study had several limitations that should be noted in the following research. First, this study does not consider brand equity factors as core brand equity factors, which Aaker (1991) asserted. The study of perceived quality in unidimensional relevant to sub-components seems to be at an initial stage. It was not easy to describe the nature of perceived quality in higher education adequately with very little earlier work. Subsequent work is needed to develop this dimension more fully. Besides that, reputation needs to investigate more about its sub-components. Overall, the results demonstrate the importance of supporting as an aspect of perceived quality and the necessity of extending our understanding of brand equity.

\section{REFERENCES}

Aaker, D. A. (1991). Managing brand equity: Capitalizing on the value of a brand name. The Free Fresh. New York.

Anderson, J. C., \& Gerbing, D. W. (1988). Structural Equation Modeling in Practice: A Review and Recommended Two-Step Approach. Psychological Bulletin, 103(3), 411-423.

Babbie, E. R. (2020). The practice of social research: Cengage learning.

Berger, K. A., \& Wallingford, H. P. (1997). Developing advertising and promotion strategies for higher education. Journal of Marketing for Higher Education, 7(4), 61-72.

Brown, K. G., \& Geddes, R. (2006). Image repair: research, consensus, and strategies: a study of the University College of Cape Breton. Journal of Nonprofit Public Sector Marketing, 15(1-2), 69-85.

Chen, Y.-F., \& Hsiao, C.-H. (2009). Applying market segmentation theory to student behavior in selecting a school or department. New Horizons in Education, 57(2), 32-43.

Dennis, C., Papagiannidis, S., Alamanos, E., \& Bourlakis, M. J. J. o. B. R. (2016). The role of brand attachment strength in higher education. 69(8), 3049-3057.

Dung, T. V. J. V. J. o. S. E., \& Business. (2019). Customer Based Brand Equity and University Brand Management. $35(4)$.

Fombrun, C., \& Shanley, M. (1990). What's in a name? Reputation building and corporate strategy. Academy of Management Journal, 33(2), 233-258.

Fornell, C., \& Larcker, D. F. (1981). Evaluating structural equation models with unobservable variables and measurement error. Journal of marketing research, 18(1), 39-50.

Gray, B. J., Shyan Fam, K., \& Llanes, V. A. (2003). Branding universities in Asian markets. Journal of Product Brand Management, 12(2), 108-120.

He, H., \& Li, Y. (2010). Key service drivers for high-tech service brand equity: The mediating role of overall service quality and perceived value. Journal of Marketing Management, 27(1-2), 77-99.

Hemsley-Brown, J., \& Oplatka, I. (2006). Universities in a competitive global marketplace: A systematic review of the literature on higher education marketing. International Journal of public sector management, 19(4), 316338.

Hu, L., \& Bentler, P. M. (1999). Cutoff criteria for fit indexes in covariance structure analysis: Conventional criteria versus new alternatives. Structural Equation Modeling: A Multidisciplinary Journal, 6(1), 1-55.

Ivy, J. (2008). A new higher education marketing mix: the 7Ps for MBA marketing. International Journal of educational management, 22(4), 288-299.

Jahanzeb, S., Fatima, T., \& Mohsin Butt, M. (2013). How service quality influences brand equity: The dual mediating role of perceived value and corporate credibility. International Journal of Bank Marketing, 31(2), 126-141. 
Keller, K. L. (1993). Conceptualizing, measuring, and managing customer-based brand equity. Journal of Marketing Intelligence Planning, 1-22.

Kurz, K., Scannell, J., \& Veeder, S. (2008). Willingness to pay: Making the best case for institutional value and return on investment. University Business, 11(5), 31-32.

Lassar, W., Mittal, B., \& Sharma, A. (1995). Measuring customer-based brand equity. Journal of consumer marketing, 12(4), 11-19.

Marginson, S. J. H. e. q. (2011). Higher education and public good. 65(4), 411-433.

Mazzarol, T., \& Soutar, G. N. (2012). Revisiting the global market for higher education. Asia Pacific Journal of Marketing and Marketing, 24(5), 717-737.

Mourad, M., Ennew, C., Kortam, W. J. M. I., \& Planning. (2011). Brand equity in higher education.

Nhung, M. T. H., Thảo, N. T., \& Thương, V. T. T. Mối quan hệ giữa các yếu tố cấu thành tài sản thương hiệu Trường Đại Học Duy Tân.

Perera, C. H., Nayak, R., \& Van Nguyen, L. T. J. I. J. o. E. M. (2020). The impact of subjective norms, eWOM and perceived brand credibility on brand equity: application to the higher education sector.

Peterson, R. A. J. J. o. c. r. (1994). A meta-analysis of Cronbach's coefficient alpha. 21(2), 381-391.

Pinar, M., Trapp, P., Girard, T., \& Boyt, T. (2011). Utilizing the brand ecosystem framework in designing branding strategies for higher education. International Journal of educational management, 25(7), 724-739.

Pinar, M., Trapp, P., Girard, T., \& E. Boyt, T. (2014). University brand equity: an empirical investigation of its dimensions. International Journal of educational management, 28(6), 18.

Santoso, S. (2015). AMOS 22 untuk Structural Equation Modelling: Elex Media Komputindo.

Sevier, R. A. (1994). Image Is Everything--Strategies for Measuring, Changing, and Maintaining Your Institution's Image. 69(2), 60-75.

Sultan, P., \& Yin Wong, H. (2012). Service quality in a higher education context: an integrated model. Asia Pacific Journal of Marketing and Logistics, 24(5), 755-784.

Thọ, N. Đ., \& Trang, N. T. M. (2002). Nghiên cứu các thành phần của giá trị thương hiệu và đo lường chúng trong thị trường hàng tiêu dùng tại Việt Nam. Đề tài nghiên cúu khoa học cấp bộ-MSB, 22-33.

Tong, X., \& Hawley, J. M. (2009). Measuring customer-based brand equity: empirical evidence from the sportswear market in China. Journal of Product Brand Management, 18(4), 262-271.

Tran, K., Nguyen, P., Do, H., \& Nguyen, L. J. M. S. L. (2020). University students' insight on brand equity. 10(9), 2053-2062.

Yoo, B., \& Donthu, N. (2001). Developing and validating a multidimensional consumer-based brand equity scale. Journal of business research, 52(1), 1-14.

Yoo, B., Donthu, N., \& Lee, S. (2000). An examination of selected marketing mix elements and brand equity. Journal of the academy of marketing science, 28(2), 195-211.

Zeithaml, V. A. (1988). Consumer perceptions of price, quality, and value: a means-end model and synthesis of evidence. Journal of marketing, 52(3), 2-22.

Ngày nhận bài: 03/12/2020

Ngày chấp nhận đăng: 22/03/2021 